\title{
Assessment of Climate Change Impacts in Greece: A General Overview
}

\author{
Maria A. Mimikou, Evangelos A. Baltas \\ Laboratory of Hydrology and Water Resources Management, Department of Water Resources, \\ Hydraulic and Maritime Engineering, Faculty of Civil Engineering, National Technical University of Athens, Athens, Greece \\ Email:mimikou@chi.civil.ntua.gr, baltas@chi.civil.ntua.gr
}

Received November 12, 2012; revised December 22, 2012; accepted December 29, 2012

\begin{abstract}
The climatic and hydrological systems are tightly related and any induced changes cause chained interactions. In an attempt to adequately manage water resources in Greece, a series of experiments were conducted with different GCMs in selected study areas to understand this interplay. This paper is an overview of the studies carried out in the Aliakmon, the Upper Acheloos, the Portaikos, and the Pinios basins, where the regional hydrological cycle was evaluated on river basin spatial scale to assess regional impacts and variability. The impacts of climate change on the water resources are presented in a synthetic quantitative way, in order to draw general conclusions concerning the trends of the hydrological indicators. A good agreement was observed between the different climatic experiments, and the trends on the selected hydrological indicators demonstrate an increase in temperature and PET, reduction in the mean annual precipitation and runoff, and a shifting of the snowmelt period towards the winter, while the snowpack storage was proved to be a controlling factor. It is accentuated that relatively small decreases in the mean annual precipitation cause dramatic increase of reservoir risk levels of annual firm water supply and energy production. As a result, radical increases of reservoir storage volume are required to maintain firm water and energy yields at tolerable risk levels. The adaptive capacity of the country is not that high, and a series of serious actions need to be taken in order to mitigate the effects of climate change and assess its impacts.
\end{abstract}

Keywords: Basin; Water Resources; Hydrological Indicators; Reservoir; Simulation Model

\section{Introduction}

The climatic and hydrological systems are interactively related and any changes initiate bidirectional feedbacks. In order to adequately manage water resources, cascadeing from climate and hydrology, it is essential to understand this interplay and thus, the hydrological cycle needs to be evaluated on a river basin spatial scale in order to assess regional impacts and variability. The climatedriven hydrological changes will be exacerbated when combined with other pressures on water resources (e.g. population growth, urbanization, deforestation etc), changes in life styles increasing water demand and environmental pollution to challenge water management in the 21 st century [1]. The importance of the climate change impacts on water resources has been identified from the Intergovernmental Panel on Climate Change (IPCC) which has recognized "water" and "regional integration" as Cross-Cutting Themes (CCT) across the IPCC Working Groups (WGs) of the Fourth Assessment Report (AR4) completed in 2007 [2]. Detecting changes in the hydrological regime that might result from climate chan- ges is complicated by the inherent variability and randomness of the climatic and hydrological variables, and distinguishing between this natural variability and the climate change impacts is challenging [3].

Nowadays, it is widely recognized that Europe is undergoing climate change and the impacts on water resources are obvious; vulnerability of hydrological extremes (floods, droughts), surface water ecosystems at risk, groundwater overexploitation, water quality degradation etc. In the last 100 years the European average temperature increased by $0.95^{\circ} \mathrm{C}$ and it is projected to further increase $2.0^{\circ} \mathrm{C}-6.3^{\circ} \mathrm{C}$ by the year 2100 . Precipitation trends have also been altered, demonstrating a high variability as south and southeastern Europe have become drier (up to $20 \%$ ), while central and northern Europe are receiving more rain than in the past $(10 \%-40 \%$ wetter). This pattern is projected to continue, with the annual precipitation decreasing up to $1 \%$ per decade in southern Europe (in summer time 5\% decrease is possible), and oppositely increasing in northern Europe by $1 \%-2 \%$ each decade [4]. Temperature and precipitation extremes are observed as in the past 100 year with the 
number of cold days decreasing and the number of summer days ( $\left.\mathrm{T} \geq 25^{\circ} \mathrm{C}\right)$ and heatwaves increasing. Wet days have decreased in southern Europe, but increased in the central and northern part, while it is projected that for the terminal year 2080 cold winters will disappear, hot summers will become more frequent, while the frequency of droughts and intense precipitation events is likely to increase. Finally, it is important to note the retreat of glaciers, snow caps and Arctic Sea ice, and the observed sea level at a rate of $0.8-3.0 \mathrm{~mm} /$ year, which can be intensified by 2.2 to 4.4 times in the future.

\section{Impacts of Climate Change on the Hydrological Cycle and the Water Resources Management, and Europe's Adaptation Potential}

Climate and land-use changes heavily influence the water balance and water resources of the different systems [5,6]. In an effort to assess the associated impacts different studies have been carried out using and establishing common indicators (such as the mean annual and seasonal runoff, mean monthly evapotranspiration (actual, potential), soil moisture, mean monthly groundwater recharge, extreme events' (flood, droughts) magnitude and frequency etc.) to allow mutual comparison. Following the temperature and precipitation trends of the altered climate, the hydrological variables are effected, thus under most climate change scenarios the mean annual streamflow is expected to increase in northern Europe and decrease in southern Europe [7,8], while a change of $10 \%$ is anticipated in mid-latitude Europe although this percentage may be smaller than the one induced by the natural mutli-decadal runoff variability (Figure 1). The change in the flow regime is highly affected by the snowfall and snowmelt and thus varies across the continent. In the Mediterranean regions, the range between winter flow and summer flow will amplify, while in the continental and upland areas where much of precipitation is in form of snow, the increased temperature will diminish snow accumulation resulting in higher winter runoff values and spring snowmelt decreases. In more continental and upland areas, where snowfall makes up a large proportion of winter precipitation, a rise in temperature would mean that more precipitation falls as rain and therefore that winter runoff increases and spring snowmelt decreases [9-11]. The above mentioned changes in the streamflow pattern, will lead to an increased river flooding risk, which seasonally will be shifted form spring to winter time. As concern is rising, several studies have been conducted by EU countries on catchment scale, in an effort to assess and mitigate the eminent problem. The effects of the European altered climate on groundwater recharge are not very obvious, but some studies in the UK and Estonia infer that it could increase

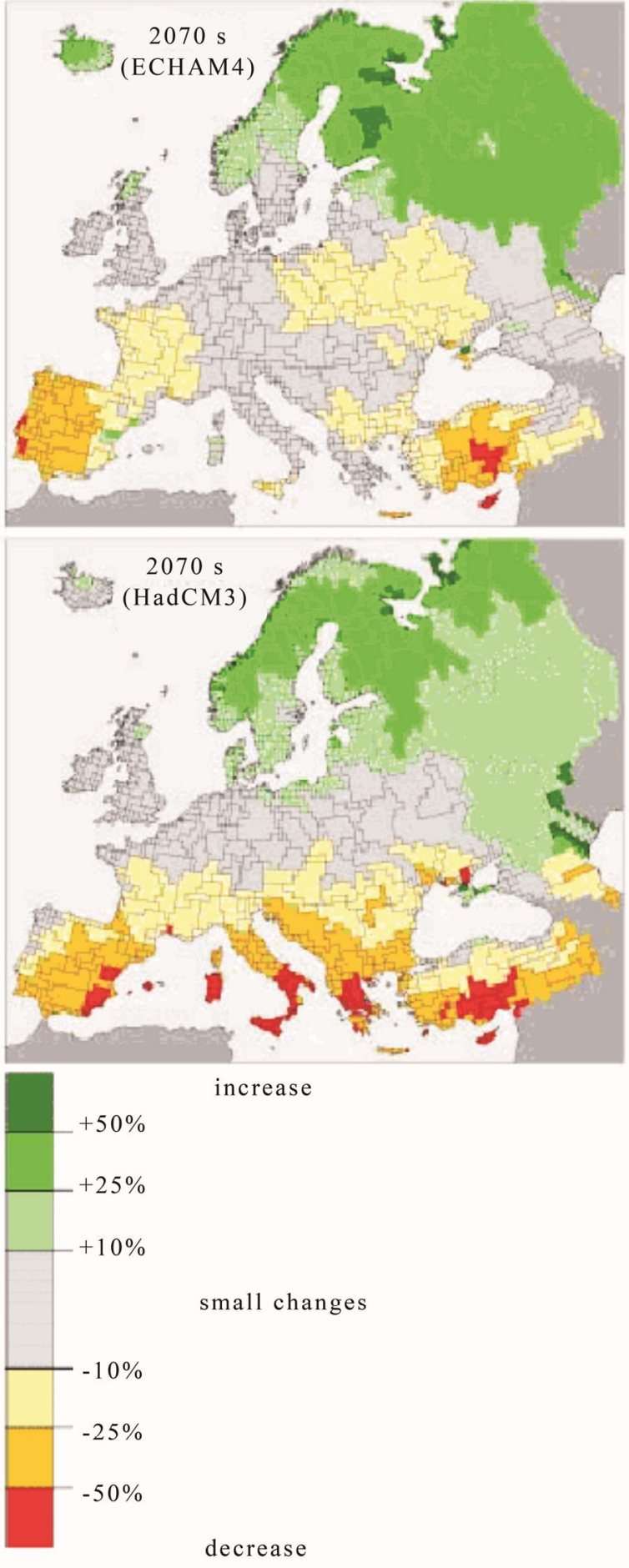

Figure 1. Change in annual average river discharge for European river basins in the 2070s compared with 2000. Note: Two different climate models (ECHAM4 and HadCM3). Source: Lehner et al., 2001.

$[12,13]$. Finally, concerning river water quality, increases in temperature and reduction in the streamflow will lead to a deteriorated quality as the stream will lose its dilution capacity, algae bloom and biological oxygen demand 
(BOD) will increase, and dissolved oxygen (DO) concentrations will diminish. A synopsis of the trends and projections of basic aforementioned indicators is presented in Table 1.

Currently, water resources in Europe are under pressure, and proper management is still problematic in many areas, as there is a major lack of communication between policy makers, stakeholders and consumers. This dramatic condition will be exacerbated by climate change [high confidence], and the most stressed systems will exhibit the highest sensitivity and vulnerability.

Climate change impacts on the hydrological cycle can trigger a series of additional impacts on water quantity and quality, such as reservoir risk, power generation inadequacy, hydraulic works failures (dams, culverts etc.), groundwater overexploitation, increased river flooding risk levels, erosion, wetland loss, seawater intrusion in coastal aquifers, water quality deterioration etc. These, in turn, will have multiple effects on the natural, social, and economic European systems [very high confidence, wellestablished evidence].

The question that clearly arises is: How will European countries be able to adapt to those impacts and mitigate the negative effects of climate change, given the uncertainty and variability that is also associated with climate change? Recently, water managers in many European countries have recognized the importance of acting in this direction, and EU directives are likely to further encourage those initiatives [14]. Generally, the adaptation potential of socioeconomic systems in Europe is relatively high because of the economic conditions (high gross national product and stable growth), the stable population (with the capacity to move within the region), and the well-developed political, institutional, and technological support systems. However, marginal and less wealthy or developed areas will adopt more difficultly, while the adaptation potential for natural systems generally is low (very high confidence) [15]. Vulnerability to climate change differs from region to region, the highestbeing in southern Europe (Mediterranean region) and in the European Arctic [16]. Those areas will face additional impacts due to sea level rise, shore loss, extended droughts, ice cap melting, increased coastal storm surge patterns, erosion etc., with major equity implications and

Table 1. Summary of trends and projections of basic indicators for Europe. Source: EEA Report, No. 2/2004.

\begin{tabular}{|c|c|c|}
\hline & INDICATORS & TRENDS \\
\hline \multirow{3}{*}{ 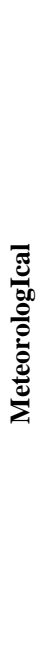 } & Annual Precipitation & $\begin{array}{l}\text { for the period } 1900-2000 \\
\text { Northern Europe } 10 \%-40 \% \text { wetter. } \\
\text { Southern Europe up to } 20 \% \text { drier. } \\
\text { for the projected future } \\
\text { Northern Europe } 1 \% \text { - } 2 \% \text { increase per decade. } \\
\text { Southern Europe up to } 1 \% \text { decrease per decade (in summer, decreases of } 5 \% \text { are possible). } \\
\text { More frequent droughts. }\end{array}$ \\
\hline & Precipitation Extremes & $\begin{array}{l}\text { for the period 1900-2000 } \\
\text { The very wet days' frequency notably decreased in recent decades in many places of } \\
\text { Southern Europe, while it increased in Mid and Northern Europe. } \\
\text { for the projected future } \\
\text { The frequency of extreme events (droughts and intense precipitation events) is likely to } \\
\text { increase by } 2080 \text {. }\end{array}$ \\
\hline & Temperature Extremes & $\begin{array}{l}\text { for the period } 1900-2000 \\
\text { Decrease of cold and frost days in most parts of Europe. } \\
\text { Increase of days with temperatures above } 25^{\circ} \mathrm{C} \text { and of heatwaves. } \\
\text { for the projected future } \\
\text { By } 2080 \text { cold winters are projected to disappear almost entirely and hot summers are } \\
\text { projected to become much more frequent. }\end{array}$ \\
\hline \multirow{2}{*}{ 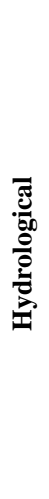 } & Annual River Discharge & $\begin{array}{l}\text { for the period } 1900-2000 \\
\text { Variability attributed to changes in precipitation, with increase in some areas (e.g. Eastern } \\
\text { Europe), and decrease in others (e.g. Southern Europe). } \\
\text { for the projected future } \\
\text { Intensification of the changes in annual river discharge, due to the combined effect of the } \\
\text { projected precipitation and temperature changes. } \\
\text { Northern \& Northeastern Europe, increase in annual discharge. } \\
\text { Southern \& Southeastern Europe, strong decline in annual discharge. }\end{array}$ \\
\hline & & $\begin{array}{l}\text { for the period 1900-2000 } \\
\text { Increase of the annual number of flood events since } 1975 \text { ( } 238 \text { events recorded), rise of the } \\
\text { number of people affected. }\end{array}$ \\
\hline
\end{tabular}


economic losses.

\section{Description of the Study Area}

Greece, located in southern Europe, has a typical Mediterranean climate, with humid winter periods and dry summer periods. The water districts presented in the study, from north to south, are the water district of Western Macedonia, Thessaly and Western Sterea. More analytically:

The water district of Western Macedonia has an extent of $13.624 \mathrm{~km}^{2}$ and is characterized by intense relief with small flat areas. The climate is continental with harsh winter and snowfalls and the mean annual temperature is $13^{\circ} \mathrm{C}$. This district presents a sufficiency in water. A great part of the water demand is covered from the transnational lakes of Small and Big Prespa, while Aliakmon river is used for the water supply of Thessalonica. The mean annual rainfall depth is $640 \mathrm{~mm}$ and the mean annual rainfall volume is estimated at $8.692 \mathrm{hm}^{3}$ [17]. The river basin of Aliakmon has the greatest extent $(8.847$ $\mathrm{km}^{2}, 65 \%$ of the extent of water district) and the river length is $93 \mathrm{~km}$. A percentage equal to $28 \%$ of the total extent corresponds to watersheds with area smaller than $40 \mathrm{~km}^{2}$. These watersheds drain directly to the sea, they are characterized by ephemeral low flow and do not contribute to the water potential of the district.

The water district of Thessaly has an extent of 13.377 $\mathrm{km}^{2}$ and includes the greatest flat terrain of the entire country, with the highest crop productivity. The development of the region depends on the promotion of intensive, irrigated agriculture and tourism. There is a dearth of water resources in the region and the demand for water of the existing crops is not covered. Therefore, a special management policy should be applied in order to reinforce the water potential through the rational use of the water resources (extension and modernization of the irrigation network), as well as through the conveyance of water capacities from other water districts. Geomorphologically, the water district is divided into three sections; the eastern coastal and mountainous, with Mediterranean climate, the central flat, with continental climate, the western mountainous, with mountainous climate.

The mean annual temperature varies between 16 and $17^{\circ} \mathrm{C}$. The rainfall depth is greater at the western part, it decreases at the flat area and increases at the eastern mountainous areas. The mean annual rainfall depth is estimated at $858 \mathrm{~mm}$ and the corresponding volume at $4.175 \mathrm{hm}^{3}$. The surface runoff is estimated at $3.202 \mathrm{hm}^{3}$. The Pinios river basin is the greatest of the country, with area equal to $10.628 \mathrm{~km}^{2}$, which corresponds to $81 \%$ of the total area of the water district. The length of the river is $255 \mathrm{~km}$.
The water district of Western Sterea is $10.199 \mathrm{~km}^{2}$ in area and is located on the high precipitation part of the country. The rivers Acheloos, Evinos and Mornos and the lake Trichonida constitute the major surface water resources of the district, in addition to the underground water resources, which generally stay unutilized. At present, a part (equal to $8.6 \%$ ) of the district's water potential is used for the water supply of Attica. A small part is also transferred to Thessaly via the Plastiras Lake. Four hydroelectric plants in Acheloos river basin have been constructed for the production of electrical energy. The mean annual rainfall depth is about $800-1000 \mathrm{~mm}$ at the coastal and flat areas, $1400 \mathrm{~mm}$ at the mountainous areas, while it exceeds $1800 \mathrm{~mm}$ at high-elevation areas. The mean annual rainfall volume is estimated at $8.680 \mathrm{hm}^{3}$, based on the mean annual rainfall depth and the extent of the water district [17]. The surface runoff is about 5.296 $\mathrm{hm}^{3}$. The river basins with area greater than $1000 \mathrm{~km}^{2}$ are those of Acheloos (5.635 $\mathrm{km}^{2}$ ) and Evinos, which cover $65 \%$ of the total extent of the district. A percentage equal to $23 \%$ corresponds to the watersheds that are smaller than $40 \mathrm{~km}^{2}$.

\subsection{The Study Basins}

Climate change impacts on the water resources and related hydraulic works have been studied for the Aliakmon river basin in northern Greece, as well as for the Upper Acheloos, the Portaikos and the Pinios river basins in central Greece (Figure 2). The study area of the Aliakmon river basin is located in northern Greece between $39^{\circ} 30^{\prime} \mathrm{S}$ and $40^{\circ} 30^{\prime} \mathrm{N}$, and $20^{\circ} 30^{\prime} \mathrm{W}$ and $22^{\circ} \mathrm{E}$.

Three subbasins of the Upper Aliakmon River, the Venetikos, the Siatista and the Ilarion basins were selected for the analysis. The Venetikos subbasin is rather mountainous with steep slopes, while the Siatista basin has

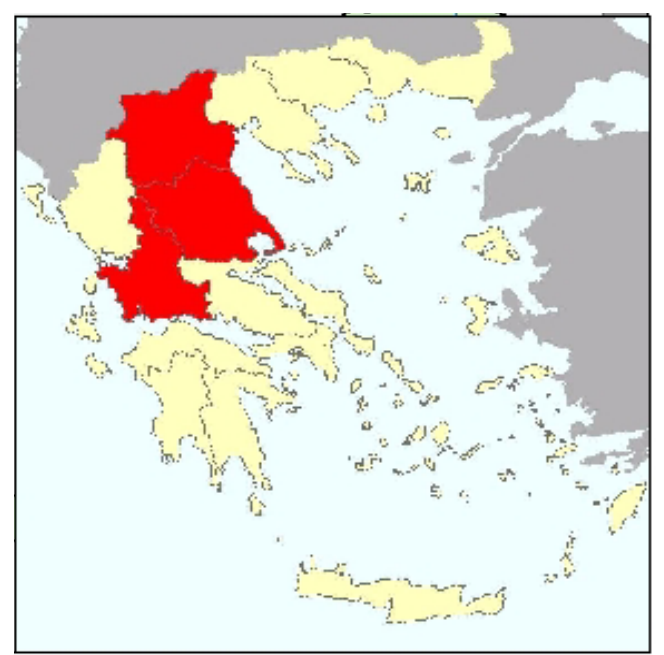

Figure 2. Location of the river basins of the selected case studies. 
milder geomorphological characteristics and flood plains. The study area of the Upper Acheloos and Portaikos River basins lies in the central mountainous region of Greece between $39^{\circ} 13^{\prime} \mathrm{S}$ and $39^{\circ} 42^{\prime} \mathrm{N}$. It comprises three drainage basins, the Mesohora and Sykia basins of the Upper Acheloos River, and the Pyli basin of the Portaikos River. The Acheloos basins are purely mountainous, while the Pyli basin lies on the slopes surrounding the plain of Thessaly. Finally, the study area of the Pinios River is situated in the Thessaly plain district. The total drainage area of the river is $9.450 \mathrm{~km}^{2}$, with a polymorphic topography varying from narrow gorges to wide flood plains. The Pinios catchments area consists of 15 subbasins drained by the main channel and its 5 tributaries, and suffers from frequent hazardous storms with conesquent flash floods that the natural capacity of the river is inadequate to pass downstream in several locations. Due to lack of sufficient data the study focused solely on the Ali Efenti subasin where reliable and long hydrometeorological time series are available. Some general characteristics of the above mentioned basins and the existing reservoirs are given in Tables 2 and 3 respectively.

\section{Current Situation and Impact Assessment on Water Resources in Greece}

The current weather conditions have major effects on the natural, environmental and socioeconomic systems in
Greece, exposing their sensitivity and vulnerability to climate, which once altered can exacerbate such effects. This is a well established evidence and calls for proper adaptation strategies in order to adequately protect the water resources of the country.

Water resources development and management is already under pressure given the current conditions, and this situation could become critical if the planners and policy makers do not take into account the projected future climate changes of higher temperature and evaporation rate, reduced streamflow patterns, shifting of the wet period, increase of extreme events (flash floods, droughts). Additionally, as the vast majority of the Greek territory lies in coastal areas, sea level rise and the associated effects of accelerated erosion, land inundation, wetland loss and groundwater regime instability, call for proactive and precautious measures. As the Greek economic conditions (gross national product and growth) are rather unstable, and gaps are observed in the institutional and technological support system, in conjunction with a population increase which leads to an increase in water demand, the adaptation potential is not high, and thus immediate intervention is needed.

Currently, according to studies of the National Observatory of Athens (NOA), an increase of $48 \%-52 \%$ in the greenhouse gases is foreseen in 2010 relative to the levels of 1990, which is much higher than upper limit of 25\% approved in 1997 in Kyoto [18]. To combat the

Table 2. General characteristics of the studied river basins.

\begin{tabular}{cccccccc}
\hline River & Subasin & Area $\left(\mathrm{km}^{2}\right)$ & 1 & 2 & 3 & 4 & 5 \\
\hline \multirow{2}{*}{ Aliakmon } & Venetikos & 818 & 1032 & 10.4 & 1069.20 & 17.7 & 0.0216 \\
& Siatista & 2724 & 1005 & 10.5 & 822.3 & 22.3 & 0.0082 \\
& Ilarion & 5005 & 917 & 11 & 825.1 & 49 & 0.0098 \\
Upper Acheloos & Mesohora & 633 & 1390 & 7.9 & 1951 & 24.4 & 0.0385 \\
\multirow{2}{*}{ Portaikos } & Sykia & 1173 & 1299 & 8.8 & 2084 & 48.4 & 0.0413 \\
Pinios & Pyli & 134.5 & 800 & 11.2 & 2023 & 65.1 & 0.484 \\
\hline
\end{tabular}

Table columns: 1) Mean elevation (m); 2) Mean annual historical temperature $\left({ }^{\circ} \mathrm{C}\right)$; 3) Mean annual historical precipitation (mm); 4) Mean annual historical runoff $\left.\left(\mathrm{m}^{3} / \mathrm{sec}\right) ; 5\right)$ Mean annual specific runoff $\left(\mathrm{m}^{3} / \mathrm{s} / \mathrm{km}^{2}\right)$.

Table 3. Designed characteristics of the studied reservoirs in the Aliakmon, Upper Acheloos and Portaikos river basins.

\begin{tabular}{cccccc}
\hline River & Reservoir & Storage Capacity $\left(10^{6} \mathrm{~m}^{3}\right)$ & Design Head $(\mathrm{m})$ & Primary energy $(\mathrm{GWh} / \mathrm{y})$ & Firm water supply \\
\hline Aliakmon & Polyfyto & $655(\mathrm{~min})-1160(\max )$ & 146.4 & $199.4(\mathrm{~min})-515(\mathrm{mean})$ & $640 \times 10^{6}\left(\mathrm{~m}^{3} / \mathrm{y}\right)$ \\
Upper Acheloos & Mesohora & 228 & 200 & 231 & - \\
Upper Acheloos & Sykia & 500 & 137 & 48.8 & $5\left(\mathrm{~m}^{3} / \mathrm{s}\right)$ \\
Portaikos & Pyli & 47 & - & - & variable \\
Portaikos & Mouzaki & 530 & 138.4 & 370 & $41\left(\mathrm{~m}^{3} / \mathrm{s}\right)$ \\
\hline
\end{tabular}


problem, Greece developed the "Hellenic Action Plan for the abatement of $\mathrm{CO}_{2}$ and other greenhouse gas emissions" in 1995, with the objective to control the increase of greenhouse gases from all sources to a maximum increase of $12 \%-18 \%$ of the 1990 level [19]. The adopted measures consider the introduction of natural gas in the industrial, commercial, tertiary and residential sectors, the modernization of the existing energy system and manufacturing units to sustain conservation, the development of cogeneration units in the power plants, the implementation of measures against energy use in transport, and the exploitation of alternative and renewable energy resources. On top of those preliminary actions, additional polices and measures where introduced in the second National Climate Change Program (2000-2010) in order for Greece to meet its Kyoto target. With the goal of reducing emissions to $25 \%$ over the time period 2008-2012, natural gas is further introduced in all demand sectors including cogeneration, energy conservation is widely imposed, renewable energy resources for electricity and heat production, as well as energy-efficient appliances are promoted, structural changes in agriculture, chemical industries, transport and waste management are introduced.

Despite the aforementioned measures and mitigation strategies, the effects of climate change on water resources in Greece are already obvious, and demonstrated indicatively by different researchers that studied the phenomenon [20-23]. The hydrological cycle is affected by the climate warming and the increased temperature causes changes in the precipitation and evaporation patterns, and the sea level. Those changes cause a chained reaction affecting the surface runoff, the soil moisture and the groundwater regime. Thus, future water resources management is at risk as the sustainability of the key aspects of water supply, agricultural water use, reservoir failure, energy production, soil drainage, flood protection, and water quality becomes vulnerable and uncertain. To combat these problems, approaches to estimate and assess the regional hydrological impacts of climate change have been attempted for the Greek territory in an effort to draw key conclusions and adequately plan for the future. The Laboratory of Hydrology and Water Resources Management of the National Technical University of Athens (NTUA) has conducted various case studies through EU funded research programs, mainly in central and northern Greece, where the major river systems are located, the results of which will be presented and discussed in the following sections. These studies, aiming in assessing the climate change impacts on selected hydrological indicators, and integrating various climate change experiments in hydrological models' simulations, follow in general the subsequent methodology: 1) Quantitative estimation of climate change using long-term climatic indices of the major climatic variables, and climatic scenarios; 2) Simulation of the hydrological cycle on catchment scale, using the aforementioned scenarios, and estimation of the climatic induced changes on different hydrological variables; 3) Estimation of the impact of the aforementioned hydrological changes on the behavior and reliability of water resources and related water management works (reservoirs, energy production, floodplain design etc.). A summary of the presented case studies' components is presented in Table 4. In the following sections the selected case studies are briefly presented, and the results and findings are summarized in combined tables to allow easy comparison.

\subsection{The Climate Change Scenarios}

To assess the effects of climate change on the study areas, the climate scenarios used where mainly outputs of experiments conducted with different General Circulation Models (GCMs). Climate change scenarios reflecting future global increase in greenhouse gas concentrations have been constructed for Europe (including Greece), at $0.5^{\circ}$ latitude/longitude resolution by the Climate Research Unit (CRU) of the University of East Anglia, England. The adopted methodology used the construction by the CRU 1961-1990 baseline climatologies for Europe, the results from different GCMs climate change experiments, and a range of global warming projections calculated by MAGICC (Model for the Assessment of Greenhouse gas Induced Climate Change), a simple upwelling-diffusion energy balance climate model [24,25]. The various climate change models employed in the studied basins, along with the corresponding terminal years are summarized in Table 5. Additionally the models ECHAM, CSIRO, CGCM were applied in Ali Efenti basin and the terminal year was 2050 .

\subsection{The Simulation Models}

For all the water balance and water quality simulations of the case studies, three basic models, two of them develed by the Laboratory of Hydrology and Water Resources Management $f$ the NTUA, and one publicly available, were used to assess the water quantity and quality of the studied basins. Additionally, for the assessment of water supply levels and the reliability of energy power producon at the studied reservoirs, a reservoir operation model was applied. The basic information of the models are briefly presented as below:

The WBUDG model is a conceptual, physically based model for the simulation the hydrological cycle using as basic inputs precipitation, temperature, wind velocity, relative humidity and sunshine duration data. The model runs on a monthly time step, and consists of various subutines which function interactively, allowing the estima- 
Table 4. Summary of the case studies components.

\begin{tabular}{ll}
\hline Components & Indices and Models \\
\hline Climatic Indices & Temperature (mean annual, seasonal, monthly) \\
& Precipitation (mean annual, seasonal, monthly) \\
& Evapotranspiration (mean annual, seasonal, monthly) \\
& Total Runoff (mean/min/max annual, seasonal, monthly) \\
& Surface, Lateral, Groundwater flow (mean monthly) \\
& Flood magnitude changes (for the 10, 20, 100, 1000 yr floods) \\
& Nitrate-nitrogen losses (mean monthly) \\
& Organic nitrogen losses (mean monthly) \\
& Sediment losses (mean monthly) \\
Assessment Indices & Ammonium NH ${ }_{4}^{+}$(mean monthly) \\
(hydrological, water quality etc.) & Biological Oxygen Demand BOD (mean monthly) \\
& Dissolved Oxygen DO (mean monthly) \\
& Reservoir Primary Energy production (mean/min annual) \\
& Risk of Reservoir annual Primary Energy production (mean, min, range) \\
& Probability of failure of the reservoir design values for water supply \\
& equilibrium: UKHI, CCC transient: HadCM2, UKTR, ECHAM, CSIRO, CGCM \\
Climatic Scenarios & WBUDG (water budget), R-Qual (water quality), SWAT (water budget, nitrogen \\
Simulation models & yield), Reservoir (water and energy supply) \\
& 2020, 2050, 2100 \\
\hline Terminal years &
\end{tabular}

Table 5. Climate change scenarios applied to the studied basins and the corresponding terminal years.

\begin{tabular}{|c|c|c|c|c|c|c|}
\hline Subasin & UKHI & $\mathrm{CCC}$ & HadCM2 & UKTR & \multicolumn{2}{|c|}{ Hypothetical T, P changes } \\
\hline Venetikos & $2020,2050,2100$ & $2020,2050,2100$ & 2050 & $2020,2050,2100$ & $+1^{\circ} \mathrm{C}, 2^{\circ} \mathrm{C}, 4^{\circ} \mathrm{C}$ & $-20 \%$ to $+20 \%(\mathrm{P})$ \\
\hline Siatista & $2020,2050,2100$ & $2020,2050,2100$ & 2050 & $2020,2050,2100$ & & \\
\hline Ilarion & $2020,2050,2100$ & $2020,2050,2100$ & 2050 & $2020,2050,2100$ & & \\
\hline Mesohora & & & & & $+1^{\circ} \mathrm{C}, 2^{\circ} \mathrm{C}, 4^{\circ} \mathrm{C}$ & $-20 \%$ to $+20 \%(\mathrm{P})$ \\
\hline Sykia & & & & & $+1^{\circ} \mathrm{C}, 2^{\circ} \mathrm{C}, 4^{\circ} \mathrm{C}$ & $-20 \%$ to $+20 \%(\mathrm{P})$ \\
\hline Pyli & & & & & $+1^{\circ} \mathrm{C}, 2^{\circ} \mathrm{C}, 4^{\circ} \mathrm{C}$ & $-20 \%$ to $+20 \%(\mathrm{P})$ \\
\hline Ali Efenti & 2050 & & 202020502100 & & & \\
\hline
\end{tabular}

on of the rain, snow, snowmelt, snow storage, groundter storage, soil moisture, actual vapotranspirations and filly stream runoff.

The R-Qual model [26] is a one-dimension finite difrences instream mathematical model derived by applying the mass conservation principles to mall completely mixed control volumes. Based on the advection disperon equation it is able to simulate temperature, BOD, DO, $\mathrm{N}-\mathrm{NO}_{3}, \mathrm{~N}-\mathrm{NO}_{2}, \mathrm{~N}-\mathrm{NH}_{4}{ }^{+}, \mathrm{N}-$ Organic, P-Dissolved, Prganic and Algae, while it runs both in steady state and dynamic mode. The model can be used to assess the imct of waste loads on in-stream water quality, or to idenfy the magnitude and quality characteristics of non-point waste loads.

The Soil and Water Assessment Tool model (SWAT), is a physically based model used to simulate the hydrogical cycle and its influence on the quantity and quality of water and sediments [27]. The model integrates the functionalities of several others, allowing the simulation of climate, hydrology, plant growth, erosion, nutrient transport and transformation, pesticide transport and management practices, erating under the ArcView plat$\mathrm{rm}$ and running on a daily time step.

The Reservoir model uses the water balance equation on a monthly time step to describe the operation of the reservoirs, taking into account constraints regarding the storage volume, the reservoir outflow nd the energy proction.

\section{Results and Discussion}

The assessment of the regional hydrological effects of the studied subasins is based on changes observed on selected hydrological indicators, such as the mean annual precipitation, mean annual potential evapotranspiration, mean annual and seasonal runoff etc. The results from the different simulation models, concerning water budget or water quality runs, and their overall performance are summarized in Table 6, where the simulation type, caliation period, time step ( $\mathrm{M}$ denotes monthly, $\mathrm{D}$ denotes 
Table 6. Summary of simulation models' performance.

\begin{tabular}{|c|c|c|c|c|c|c|}
\hline River & Subasin & Model & Simu lation type & Calibra tion period & Time step & $\begin{array}{l}\text { Nash-Sutcliffe } \\
\text { coefficient NTD }\end{array}$ \\
\hline \multirow{4}{*}{ Aliakmon } & Venetikos & WBUDG & 1 & A & M & 0.860 \\
\hline & Siatista & WBUDG & 1 & A & M & 0.850 \\
\hline & Ilarion & WBUDG & 1 & A & M & 0.850 \\
\hline & Polyfyto reservoir & Reservoir & 2 & A & M & \\
\hline \multirow{4}{*}{$\begin{array}{c}\text { Upper } \\
\text { Acheloos }\end{array}$} & \multirow{2}{*}{ Mesohora } & WBUDG & 1 & B & M & 0.864 \\
\hline & & Reservoir & 2 & B & M & \\
\hline & \multirow{2}{*}{ Sykia } & WBUDG & 1 & B & M & 0.882 \\
\hline & & Reservoir & 2 & B & M & \\
\hline \multirow{2}{*}{ Portaikos } & Pyli & WBUDG & 1 & $\mathrm{C}$ & M & 0.911 \\
\hline & Mouzaki & Reservoir & 2 & B & M & \\
\hline \multirow{5}{*}{ Pinios } & & WBUDG & 1 & $\mathrm{D}$ & M & 0.6 \\
\hline & & R-Qual & 3 & $\mathrm{E}$ & M & \\
\hline & Ali Efenti & SWAT & 1 & F & M,D & $0.81(\mathrm{M})$ \\
\hline & & & & & & $0.62(\mathrm{D})$ \\
\hline & & & 4 & $\mathrm{~F}$ & M,D & 0.75 \\
\hline
\end{tabular}

Table columns: 1 Water budget; 2 Water and Energy supply; 3 Water quality (BOD, DO, $\mathrm{NH}_{4}^{+}$); 4 Nitrogen yield; A: $1961-1990$ (30 yrs); B: $1971-1986$ (15 yrs); C: 1971-84, 1986 (15 yrs); D: 1960-1996 (36 yrs); E: 1988-1991 (3 yrs); F: 1970-1993 (23 yrs).

daily), and goodness of fit statistics are presented.

As summarized in Table 6, the water budget and qualty models that were used in the different cases performed successfully and accurately in reproducing the hydrological conditions, and the calibration results as assessed with the Nash-Sutcliffe coefficient were satisfactory.

The available data used in the calibration process varied in general from 15 to 30 years, which is a good time range to be able to draw conclusions on the reliability on the simulations. The quality and accuracy of the available data was adequate, although more data would give even better confidence on the models' results. An assessment of the hydrological impacts of the different experiments that have been performed for the case studies for the terminal year 2050, and the respective results are illustrated in Table 7. In this table the climatically induced changes in a series of indicators, such as: mean annual precipitation, snow, potential evapotranspiration, runoff, summer runoff, winter runoff, maximum annual runoff, minimum annual runoff, flood peaks for the 20,100, 1000 year return periods, mean annual $\mathrm{BOD}, \mathrm{DO}, \mathrm{NH}_{4}{ }^{+}$, nitratenitrogen loss, and sediment loss-are presented in qualitative terms by using the signs " + " to denote an increase, "-" to denote a decrease, and " $=$ " to symbolize no change on the hydrological or water quality indicators.

As inferred from this table, the trends on the indicators' changes are almost consistent for all the examined case studies. Based on these results, and the experience gained from all the case studies, the following conclusions can be derived:

> A good agreement was observed between the different climatic experiments. The climatically induced changes on the hydrological variables were consistent, although the transient experiments attributed higher changes of the hydrological indicators in comparison with the equilibrium experiments. It worth noticing that the CCC equilibrium scenario had some discrepancy with the other scenarios, and predicted increases in the maximum annual runoff when the rest produced decreases.

> The selected hydrological indicators were adequate, and allowed the intercomparison of the results to lead to some generalized conclusions.

> General trends of the climate change hydrological impacts were observed in all basins, such as: temperature increase, potential evapotranspiration increase, reduction in the mean annual and summer precipitation, reduction in the mean annual and summer runoff, reduction in the minimum and maximum annual runoff with extension of the dry summer period, and shifting of the snowmelt period towards the winter.

Snowpack storage is a governing factor. The basins where a significant retention of precipitation occurs in the form of snowpack storage, exhibit a great sensiti- 
Table 7. Summary of the results of the case studies.

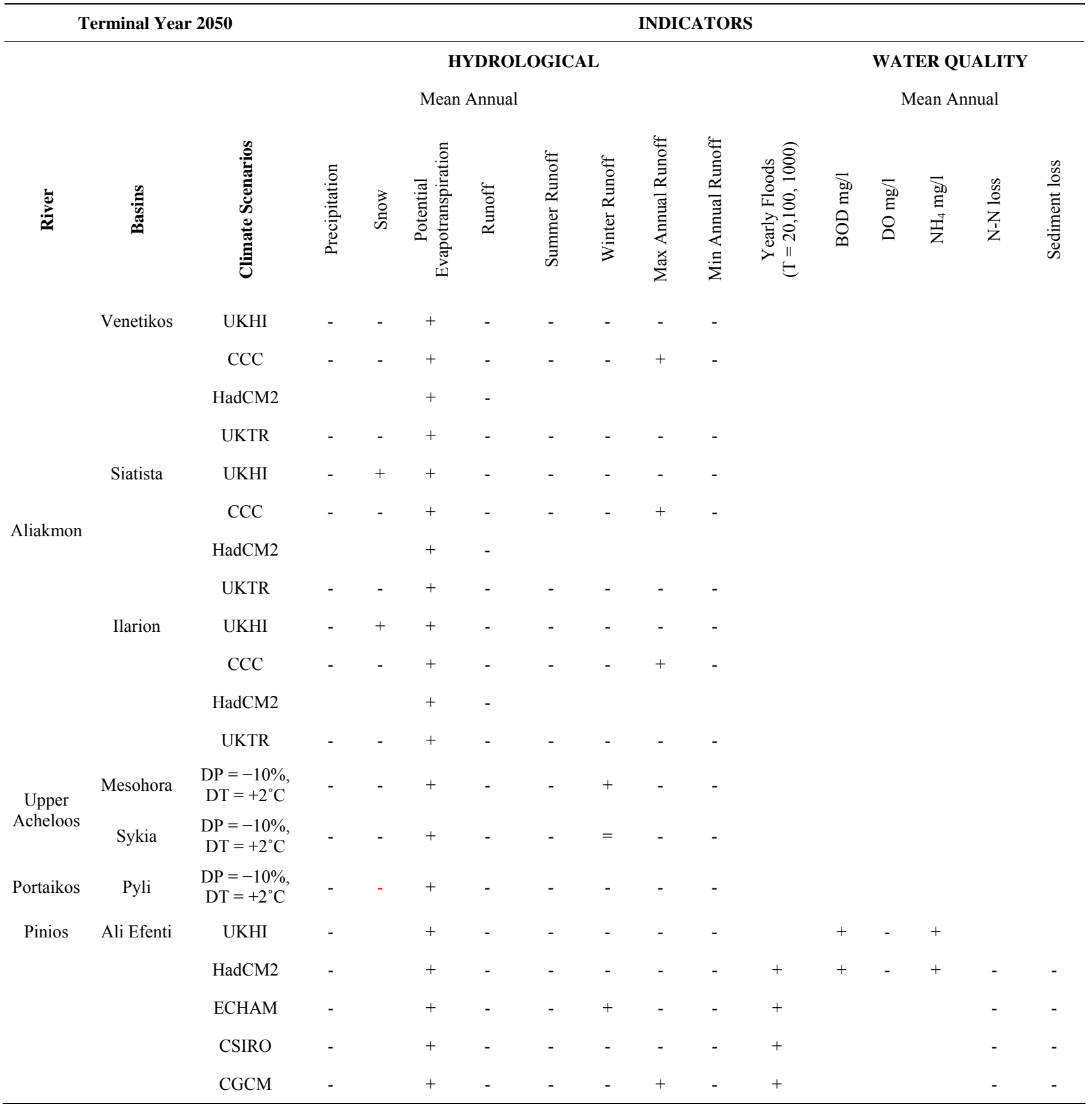

vity in temperature increase, which is reflected with serious reduction of mean and minimum annual runoff, even more serious reduction of summer runoff, and a significant increase of the maximum annual and winter runoff. On the other hand, in the absence of significant snowpack storage, temperature increases are restricted to affect runoff only through the evapotranspiration process and those basins are not as sensitive to them.

A magnification factor characterizes the effect of precipitation change on runoff, and can be considered as a measure of basin sensitivity to precipitation change. Regarding annual runoff, the magnification factor seems to be independent of temperature and positively associated with basin aridity, whereas on a seasonal basis it depends on the presence of winter snow cover and consequently temperature increases.

The local physiographic characteristics of the basin are important as they shape basic parameters, such as the runoff coefficient which, when usually high, does not permit other hydrological processes, sensitive to climate change, to be accomplished or even take 
place at all.

$>$ Climate change has an important, but by no mean determining, role in the growth of floods. The uncertainty while moving in a finer time scale (daily) is still large, abd the use of different GCM outputs and simple downscaling techniques can lead to adverse results. However, there is evidence of increasing flood magnitude.

$>$ Changes in precipitation have a pronounced effect of water quality. Reduced stream flows lead to loss of the stream's dilution capacity, and thus increased BOD and $\mathrm{NH}_{4}^{+}$, and decrease DO values are observed, especially during the summer months, as well as reduced losses for both nitrate and organic nitrogen.

Concerning the conducted reservoir risk analyses, a dramatic increase of risk levels of annual firm water supply and energy production (for both the minimum and mean annual) was exhibited under the examined plausible climate change scenarios. The reservoirs were found to be very sensitive to precipitation decreases. Although the probability of failure associated with the design values of $\mathrm{W}$ and $\mathrm{E}$ is currently well below $1 \%$, when facing reduction in precipitation the probability of failure ranges form $20 \%$ up to $60 \%$. Radical increases of reservoir storage volume are required for all the reservoirs in order to maintain firm water and energy yields at tolerable risk levels. Downstream reservoirs are more sensitive than the upstream ones, and this is attributed to the cumulative effect of upstream failures being transferred downstream. The effect o temperature increase is also associated with risk levels, but was marginal when compared with precipitation reductions.

\section{Conclusions}

Global climate change has major impacts on the water resources and the related hydraulic works. In an effort to assess those impacts, different climatic scenarios are integrated in hydrological models and many studies use this approach to project the future status, draw conclusions and plan adequately. The most common problem is the spatial and time scales mismatch between the global climate models and the regional river basins. Additionally, the selection of suitable hydrological indicators, and the development of robust and realistic hydrological models that produce high confidence simulated results need to be thoroughly examined.

The European continent in undergoing climate change with a projected increase in temperature of $2.0^{\circ} \mathrm{C}-6.3^{\circ} \mathrm{C}$ in the year 2100. As a result the south is becoming drier, while the northern and southern areas are receiving more rain, manifesting the exacerbation of the extreme hydrological events (droughts, floods). The impacts on the water resources, which in many regions are already under pressure, are obvious (reservoir risk, power generation shortage, failure of hydraulic works etc.) and call for adequate policy measures. Although vulnerability to climate change is substantial, the adaptation potential of the European socioeconomic systems is relatively high due to the population stability, the well developed political and institutional support systems, and the economic conditions.

Greece follows the European climate change trends, demonstrating increases in temperature and evapotranspiration, reductions in precipitation and runoff, and a prolongation of dry summer periods. The adaptive capacity of the country though, is not that high, and a series of serious actions need to be taken in order to mitigate the effects of climate change and assess its impacts. It is accentuated that relatively small decreases in the mean annual precipitation cause dramatic dramatic increase of reservoir risk levels of annual firm water supply and energy production. As a result, radical increases of reservoir storage volume are required to maintain firm water and energy yields at tolerable risk levels. Climate change has similar impacts on other hydraulic works, such as groundwater supplies, flood protection measures, erosion prevention structures etc.

Although many studies have so far been conducted with the purpose of assessing the impacts of climate change at European level, mainly through the implementtation of different EU funded projects, they remain scattered and thus their findings are not fully exploited. Coordinated actions need to be initiated from the European Community, focusing, on one hand, on planning a common concrete strategy for studying the effects of climate change on water resources (e.g. selection of common hydrological indicators), and strengthening, on the other hand, the policy initiatives in order to combat the problem and better assess the impacts following the global standards of the IPCC.

\section{REFERENCES}

[1] Z. W. Kundzewicz, L. J. Mata, N. W. Arnell, P. Döll, P. Kabat, B. Jiménez, K. A. Miller, T. Oki, Z. Sen, I. A. Shiklomanov, "The Implications of Projected Climate Change for Freshwater Resources and Their Management," Journal of Hydrological Sciences, Vol. 53, No. 1, 2008, pp. 3-10.

[2] IPCC (Intergovernmental Panel on Climate Change), "Fourth Assessment Report, "Climate Change 2007: Synthesis Report," Cambridge University Press, Cambridge.

[3] A. J. Askew, "Climate Change and Water Resources," IAHS Publ., Vol. 168, 1987, pp. 421-430.

[4] EEA (European Environmental Agency), "Impacts pf Europe's Changing Climate, an Indicator-Based Assessment," EEA Report No 2/2004, EEA, Copenhagen, 2004.

[5] L. Ryszkowski, A. Kedziora and J. Olejnik, "Potential Effects of Climate and Land Use Changes on the Water 
Balance Structure in Poland," In: Processes of Change: Environmental Transformation and Future Patterns, Kluwer Academic Publishers, Dordrecht, 1990, pp. 253-274.

[6] J. Olejnik and A. Kedziora, "A Model for Heat and Water Balance Estimation and Its Application to Land Use and Climate Variation," Earth Surface Processes and Landforms, Vol. 16, No. 7, 1991, pp. 601-617. doi:10.1002/esp.3290160705

[7] N. W. Arnell, "The Effect of Climate Change on Hydrological Regimes in Europe: A Continental Perspective," Global Environmental Change, Vol. 9, No. 2, 1999, pp. 5-23. doi:10.1016/S0959-3780(98)00015-6

[8] B. Lehner, T. Henrichs, P. Döll and J. Alcamo, "EuroWasser: Model-Based Assessment of European Water Resources and Hydrology in the Face of Global Change," Vol. 5, Centre for Environmental Systems Research, University of Kassel, Kassel, 2001.

[9] J. Hladny, J. Buchtele, M. Doubková, V. Dvorák, L. Kaspárek, O. Novicky and E. Prenosilová, "Impact of a Potential Climate Change on Hydrology and Water Resources: Country Study of Climate Change for the Czech Republic," National Climate Program of the Czech Republic, Czech Republic, Prague, 1997, p. 137.

[10] L. Kasparék, "Regional Study on Impacts of Climate Change on Hydrological Conditions in the Czech Republic," Prace a Studie, Vol. 193, 1998, p.70.

[11] K. Hlavcová and J. Cunderlík, "Impact of Climate Change on the Seasonal Distribution of Runoff in Mountainous Basins in Slovakia," In: Hydrology, Water Resources, and Ecology in Headwaters, IAHS Publication, No. 248, 1998, pp. 39-46.

[12] N. W. Arnell and N. S. Reynard, "Climate Change and British Hydrology," In: M. C. Acreman, Ed., The Hydrology of the UK, Routledge, London, 1999, pp. 3-29.

[13] A. Jarvet, "Estimation of Possible Climate Change Impact on Water Management in Estonia," Proceedings of the Second International Conference on Climate and Water, Espoo, 1998, pp. 1449-1458.

[14] EEA (European Environmental Agency), "Climate Change and Water Adaptation Issues," EEA Technical Report No 2/2007, EEA, Copenhagen, 2007.

[15] IPCC (Intergovernmental Panel on Climate Change) Third Assessment Report, "Climate Change 2001: Working Group II: Impacts, Adaptation and Vulnerability," Cambridge University Press, Cambridge.

[16] EEA (European Environmental Agency), "Vulnerability and Adaptation to Climate Change in Europe," Technical report No 7/2005, EEA, Copenhagen, 2005.

[17] E. Baltas, "Climatic Conditions and Availability of Water Resources in Greece," International Journal of Water Resources Development, Vol. 24, No. 4, 2008, pp. 635-649. doi:10.1080/07900620802230129

[18] Observatory of Athens (NOA). http://www.noa.gr.

[19] Greece 3rd National Communication to the UNFCCC, "Policies and Measures."

[20] G. Lambrakis and G. Kallergis, "Reaction of Subsurface Coastal Aquifers to Climate and Land Use Changes in Greece: Modelling of Groundwater Refreshening Patterns under Natural Recharge Conditions," Journal of Hydrology, Vol. 245, No. 1-4, 2001, pp. 19-31.

[21] E. Baltas and M. Mimikou, "Climate Change Impacts on the Water Supply of Tessaloniki," International Journal of Water Resources Development, Vol. 21, No. 2, 2005, pp. 341-353. doi:10.1080/07900620500036505

[22] D. Panagoulia, "Catchment Climatological Data and Climate Change in Continental Greece," Proceedings of the Intertnational Conference on Development and Application of Computer Techniques to Environmental Studies, Vol. 2, 1994, p. 29.

[23] E. Varanou, E. Gkouvatsou, E. Baltas and M. Mimikou, "Quantity and Quality Integrated Catchment Modeling under Climate Change with Use of Soil and Water Assessment Tool Model," Journal of Hydrologic Engineering, Vol. 7, No. 3, 2002, pp. 228-244. doi:10.1061/(ASCE)1084-0699(2002)7:3(228)

[24] M. Hulme, D. Conway, O. Brown and E. Barrow, "A 1961-1990 Baseline Climatology and Future Climate Change Scenarios for Great Britain and Europe," Climatic Research Unit, University of East Anglia, Norwich, 1994.

[25] CRU (Climate Research Unit), "Global Average Temperature Change 1856-2003," 2003. http://www.cru.uea.ac.uk/cru/data/temperature/

[26] M. Mimikou, E. Baltas, E. Varanou and K. Pantazis, "Regional Impacts of Climate Change on Water Resources Quantity and Quality Indicators," Journal of Hydrology, Vol. 234, No. 1-2, 2000, pp. 95-109. doi:10.1016/S0022-1694(00)00244-4

[27] J. G. Arnold, J. R. Williams, R. Srinivasan and K. W. King, "SWAT: Soil and Water Assessment Tool," US Deptartment of Agriculture, Agricultural Research Service, Temple, 1994. 